\title{
Omega-3 supplementation, milk quality and cow immune-competence
}

\author{
Andrea Bragaglio, ${ }^{1}$ Ada Braghieri, ${ }^{1}$ Fabio Napolitano, ${ }^{1}$ Giuseppe De Rosa, ${ }^{2}$ \\ Amelia Maria Riviezzi, ${ }^{1}$ Francesca Surianello, ${ }^{1}$ Corrado Pacelli ${ }^{1}$ \\ 'Scuola di Scienze Agrarie, Forestali, Alimentari ed Ambientali, Università della Basilicata, \\ Potenza; ${ }^{2}$ Dipartimento di Agraria, Università Federico II di Napoli, Portici (NA), Italy
}

\begin{abstract}
This study aimed to assess the effect of a dietary supplementation rich in n-3 fatty acids from algae (Schizochytrium sp.) on cow immune-competence and milk quality. Twenty-one lactating Italian Friesian cows (at $220 \pm 20$ days of lactation) were equally allocated to 3 treatments: group $\mathrm{C}$ received no supplementation, group D was offered $136 \mathrm{~g}$ of docosahexaenoic acid (DHA) per day and group E was supplemented with $136 \mathrm{~g}$ of DHA + 2000 U.I. of vitamin E per day. Individual milk production was recorded weekly and samples were collected for analysis of milk composition and fatty acid profile. At the end of the trial and 2 weeks later animals were subcutaneously injected with 5 mg of keyhole limpet haemocyanin (KLH), whereas at the end of the trial and 8 weeks later skinfold thickness was measured after intradermal injection with $500 \mathrm{mg}$ phytohaemagglutinin. Dietary treatment showed no effect on milk production. Concentrations of DHA were higher $(\mathrm{P}<0.05)$ in milk fat from $\mathrm{D}$ and $\mathrm{E}$ groups, whereas polyunsaturated fatty acids tended to be higher $(\mathrm{P}<0.10)$. When DHA and DHA + vitamin E were supplemented to the animals, milk sensory properties were significantly modified as samples from groups D and E could be discriminated from the control using the triangle test $(\mathrm{P}<0.001)$. Both supplemented groups showed evidence of increased antibody response 4 to 8 weeks after the first KLH administration $(\mathrm{P}<0.05)$. In
\end{abstract}

Correspondence: Andrea Bragaglio, Scuola di Scienze Agrarie, Forestali, Alimentari ed Ambientali, Università della Basilicata, viale dell'Ateneo Lucano 10, 85100 Potenza, Italy.

E-mail: andrea.bragaglio@unibas.it

Key words: marine algae, n-3 fatty acids, cow immune-competence, milk fatty acid, milk sensory properties.

Acknowledgments: the authors are grateful to Giovanni Migliori for expert technical assistance.

Conference presentation: Meeting on Environmental Sustainability and Food Security, Potenza, Italy, 2014.

Received for publication: 8 July 2014

Revision received: 2 December 2014.

Accepted for publication: 4 December 2014.

(C) Copyright A. Bragaglio et al., 2015

Licensee PAGEPress, Italy

Italian Journal of Agronomy 2015; 10:611

doi:10.4081/ija.2015.611

This article is distributed under the terms of the Creative Commons Attribution Noncommercial License (by-nc 3.0) which permits any noncommercial use, distribution, and reproduction in any medium, provided the original author(s) and source are credited. the two skin tests the treated groups showed a higher skin thickening in comparison with control animals $(\mathrm{P}<0.05)$.

Although provided in a late stage of lactation, an $n-3$ fatty acid enriched diet favourably changed milk fatty acid profile and promoted animal healthiness by enhancing cellular and humoral immune response.

\section{Introduction}

Dairy milk has many health benefits in preventing osteoporosis (Huth et al., 2006) and as source of components such as conjugated linoleic acid, exhibiting anti-inflammatory, immunomodulatory, antiobesity, and anti-carcinogenic activities (Shingfield et al., 2008). However, milk contains high concentrations of saturated fats (SFA) (Jenkins and McGuire, 2006), involved as a factor for increased risk of heart disease (Huth and Park, 2012). Conversely, the polyunsaturated fatty acids (PUFA), and especially n-3 fatty acids, having a potential antiatherogenic, anti-obesity and anti-carcinogenic role (Riediger et al., 2009), are only 4\% of the milk fatty acids (Mansbridge and Blake, 1997).

Many attempts have been made to alter the fatty acid composition of milk fat from dairy cows to improve the nutritional value for consumers (Jenkins and McGuire, 2006). The inclusion of plant (rapeseed, soybean and linseed) or fish oil rich in unsaturated fatty acid (UFA) into animal diets may modify the fatty acid composition of body tissues and products of animal origin (Collomb et al., 2004). The increase in the concentration of very long chain n-3 fatty acids in milk fat, such as eicosapentaenoic acid C20:5 n-3 (EPA) and docosahexaenoic acid C22:6 n-3 (DHA), can be efficiently achieved by feeding marine oil from fish, mammals, plankton or algae (Chilliard et al., 2001). Marine oils are rich in long-chain (C20-C22) PUFA, of which EPA and/or DHA are the most important (Arab-Tehrany et al., 2012). The effect of feeding marine algae is slightly different, with increases in milk DHA and docosapentaenoic acid (DPA) (22:5n-3), as well as in C22:5 n-6 and C20:4 n-6, but not in EPA (Barclay et al., 1998; Franklin et al., 1999). This particular effect of marine algae is related to their FA composition. Some families of marine algae (Schizochytrium sp.), in fact, are rich in DHA (25\%) and C22:5 n-6 (12\%), but poor (1\%) in EPA (Barclay et al., 1998). Fatty acid profile determines many of the physical, organoleptic, and nutritional characteristics of milk and dairy products (Chilliard et al., 2001). However, certain feeding regimes increasing the content of polyunsaturated lipids make the milk more vulnerable to oxidation (Arab-Tehrany et al., 2012). Cow supplementation with fish oil in order to increase PUFA content of dairy products may cause the production of off-flavours due to the high susceptibility to oxidation of PUFA (Nelson and Martini, 2009), promoted by both transition metals and unsaturated phospholipids present in the milk fat globule (Fox and McSweeney, 1998). However, numerous researches have shown that antioxidants such as tocopherols and carotenoids can be transferred from the feed to the milk and thereby improve the oxidative stability of milk (Granelli et al., 1998). 
Omega 3 PUFA are considered as important modulators of immune reactions (Calder et al., 2002) as shown in experimental animal models (Pomposelli et al., 1989) and in clinical trials (Stenson et al., 1992). Mechanisms involved in the regulation of immune response may be related to PUFA influence on cellular communication and activation through the synthesis of prostaglandins, tumour necrosis factor- $\alpha$, interferon- $\gamma$, and other factors such as nitric oxide (Calder et al., 2002).

The aim of this study was to increase the level of $n-3$ fatty acids in milk from dairy cows using marine algae as source of long chain $n-3$ fatty acids and vitamin E supplementation as antioxidant. The influence of algae administration, with or without vitamin $\mathrm{E}$ on sensory properties and rheological traits of milk was also assessed. In addition, the effect of dietary n-3 fatty acids and their interaction with vitamin $\mathrm{E}$ on humoral and cellular immune responses and on blood metabolites was evaluated.

\section{Materials and methods}

\section{Animals and experimental design}

Twenty-one multiparous Italian Friesian cows at $220 \pm 20$ days of lactation were equally allocated to 3 treatments. The main characteristics of the ration are summarised in Table 1 . All the animals were fed for the first 2 weeks a control diet. From week 3 to 6 the control diet in group D was supplemented with $136 \mathrm{~g}$ of DHA Gold (Omegatech, Inc., Boulder, CO, USA) per day and in group E with $136 \mathrm{~g}$ of DHA Gold + 2000 U.I. of vitamin E per day. DHA Gold is a supplementation based on microalgae with a $30 \%$ of ruminal protection, containing $37 \%$ of DHA (Table 2). Group $\mathrm{C}$ received no supplementation and was used as control. Cows were milked twice per day (05.00 and $17.00 \mathrm{~h})$.

\section{In vivo cell-mediated immunity}

The phytohaemagglutinin (PHA) skin test was performed to induce aspecific delayed-type hypersensivity. At the end of the supplementation period and 8 weeks later, PHA (phytohaemagglutinin, $500 \mu \mathrm{g}$; Sigma-Aldrich, St. Louis, M0, USA), dissolved in $500 \mu \mathrm{L}$ of sterile saline solution, was injected intra-dermally into the middle of two $2 \mathrm{~cm}$ wide circles stamped on shaved skin in the upper side of each shoulder. The skinfold thickness was determined before PHA injection and $24 \mathrm{~h}$ after with a calibre. For each animal an average increase in skinfold thickness (24 h thickness - pre-injection thickness) was computed using the 2 measurements gathered from each shoulder.

\section{Antibody production}

At the end of the supplementation period and 2 weeks later, animals were subcutaneously injected with $5 \mathrm{mg}$ ( $2.5 \mathrm{mg}$ per shoulder) of keyhole limpet haemocyanin (KLH, Sigma-Aldrich), dissolved in $2 \mathrm{~mL}$ of sterile saline solution and emulsified in an equal volume of incomplete Freund's adjuvant. Antibody titer was evaluated on serum collected from jugular vein using vacuum tubes at weekly intervals for eight weeks. An enzyme-linked immunosorbent assay (ELISA) was performed in 96-well, U-bottomed microtiter plates. Wells were coated with $100 \mu \mathrm{L}$ of antigen $(0.5 \mathrm{mg}$ of $\mathrm{KLH} / \mathrm{mL}$ of phosphate buffer $)$ at $4^{\circ} \mathrm{C}$ for 12 $\mathrm{h}$ washed and incubated at $37^{\circ} \mathrm{C}$ for $1 \mathrm{~h}$ to reduce non-specific binding. After washing, the serum [1:1600 dilution in phosphate buffered saline (PBS); $100 \mu \mathrm{L}$ per well] was added and incubated at $37^{\circ} \mathrm{C}$ for $1 \mathrm{~h}$. Buffer alone provided negative control wells. The extent of antibody binding was detected using a horseradish peroxidase-conjugated antibovine immunoglobulin G (Sigma-Aldrich). Plates were again incubated for $1 \mathrm{~h}$ at $37^{\circ} \mathrm{C}$ after washing and adding $100 \mu \mathrm{L}$ per well of conjugate (1:48,000 in PBS). Buffer alone provided blank wells. Following a further washing $100 \mu \mathrm{L}$ of substrate ( $1 \mathrm{mg}$ of tetra methyl benzidine free base tablets, $1 \mathrm{~mL}$ dimethyl sulfoxide, $9 \mathrm{~mL}$ posphate-citrate buffer, $2 \mu \mathrm{L} \mathrm{H}_{2} \mathrm{O}_{2}$ ) was added to each well. After $30 \mathrm{~min} 50 \mu \mathrm{L}$ of $2 \mathrm{M} \mathrm{H}_{2} \mathrm{SO}_{4}$ was added to terminate reactions. Optical density was measured at a wavelength of $450 \mathrm{~nm}$ using an ELISA reader. The intra- and inter-assay coefficient of variations were 3.5 and $6.5 \%$, respectively. The assay was optimised in our laboratory for concentrations of coating antigen, serum and detector antibody.

\section{Milk chemical analyses}

Individual milk production was recorded and samples were collected weekly for composition analyses. Total protein, fat and lactose contents were determined by the automated infrared method, using

Table 1. Ingredients and composition of the experimental diets offered to control animals (group $\mathrm{C}$ ) and to animals supplemented with docosahexaenoic acid (DHA) (group D) or DHA + vitamin E (group E).

\begin{tabular}{lccc} 
& \multicolumn{3}{c}{ Diets } \\
& C & D & E \\
Ingredients & & & \\
Triticale silage, $\mathrm{kg} / \mathrm{d}$ & 15 & 15 & 15 \\
Corn silage, $\mathrm{kg} / \mathrm{d}$ & 9 & 9 & 9 \\
Concentrate*, $\mathrm{kg} / \mathrm{d}$ & 7 & 6.8 & 6.8 \\
Meadow hay, $\mathrm{kg} / \mathrm{d}$ & 6 & 6 & 6 \\
Barley meal, kg/d & 2.5 & 2.5 & 2.5 \\
Faba beans, $\mathrm{kg} / \mathrm{d}$ & 0.5 & 0.5 & 0.5 \\
DHA-Gold, $\mathrm{g} / \mathrm{d}$ & - & 136 & 136 \\
Vitamin E, U.I. & - & - & 2000 \\
Composition, \% of DM & & & \\
Crude protein & 15.3 & 15.3 & 15.3 \\
Ether extract & 3.6 & 4.0 & 4.0 \\
Crude fibre & 19.9 & 19.9 & 19.9 \\
NDF & 38 & 38 & 38 \\
Ash & 7.6 & 7.6 & 7.6 \\
MFU/kg DM & 0.89 & 0.89 & 0.89 \\
\hline
\end{tabular}

DM, dry matter; NDF, neutral detergent fibre; MFU, milk forage unit. *Wheat flour middling, soybean meal, corn meal, barley meal, hydrogenated palm oil, calcium carbonate, sodium bicarbonate, magnesium oxide, vitamins; crude protein, $26 \%$ of DM; ether extract, $9.5 \%$ of DM; crude fibre, $4 \%$ of DM; ash, $6 \%$ of DM.

Table 2. Chemical (\% of dry matter) and fatty acid composition (\% of total fatty acids) of docosahexaenoic acid supplementation.

\begin{tabular}{lc}
\hline Chemical composition & \\
Dry matter & 96.0 \\
Crude protein & 14.5 \\
Ether extract & 49.5 \\
Crude fibre & 0.5 \\
Ash & 8.5
\end{tabular}

\begin{tabular}{lc} 
Fatty acid composition & \\
C14:0 & 10.0 \\
C16:0 & 23.0 \\
C16:1 & 1.8 \\
C18:0 & 0.5 \\
C18:1 n-9 & 6.2 \\
C18:3 n-3 & 2.7 \\
C20:3 n-6 & 2.3 \\
C20:5 n-3 (EPA) & 2.5 \\
C22:5 n-6 (DPA) & 13.5 \\
C22:6 n-3 (DHA) & 37.5 \\
\hline
\end{tabular}

EPA, eicosapentaenoic acid; DPA, docosapentaenoic acid; DHA, docosahexaenoic acid. 
a Milko-Scan 255 (Foss Electric, Hillerød, Denmark).

For the determination of milk fatty acids, lipids were extracted from milk (10 mL) samples using the method of Bligh and Dyer (1959) and methylated adding $1 \mathrm{~mL}$ of heptane and $0.05 \mathrm{~mL}$ of $2 \mathrm{~N}$ methanolic potassium hydroxide (IUPAC, 1987). Fatty acid methyl esters (FAME) (IUPAC, 1987) were analysed on a Varian chromatograph (model Star $3400 \mathrm{CX}$ ). Separations were performed using a CP-88 capillar column $(100 \mathrm{~m} \times 0.25 \mathrm{~mm}$ i.d. $\times 0.25 \mu \mathrm{m})$. Operating conditions were: a helium flow rate of $0.7 \mathrm{~mL} / \mathrm{min}$, a flame ionization detector detector at $250^{\circ} \mathrm{C}$, a split-splitless injector at $230^{\circ} \mathrm{C}$ with an injection rate of $120 \mathrm{~mL} / \mathrm{min}$, an injection volume of $1 \mu \mathrm{L}$. The temperature programme of the column was: $3 \mathrm{~min}$ at $40^{\circ} \mathrm{C}$ and an increase of $10^{\circ} \mathrm{C} / \mathrm{min}$ to $150^{\circ} \mathrm{C}$ for $3 \mathrm{~min}$ and a subsequent increase of $4^{\circ} \mathrm{C} / \mathrm{min}$ to $150^{\circ} \mathrm{C}$ for $25 \mathrm{~min}$. Retention time and area of each peak were computed using the Varian Star 3.4.1. Software. Individual fatty acids were identified by retention time with reference to fatty acid standard mixtures (Supelco 37 Component FAME mix, Supelco, Bellefonte, PA, USA). Results were expressed as relative percentages.

\section{Sensory evaluation}

Milk samples from cows fed control, D and E diets were pasteurised at $65.5^{\circ} \mathrm{C}$ for $30 \mathrm{~min}$ (with occasional agitation), rapidly cooled and stored at $4^{\circ} \mathrm{C}$. Milks were evaluated (Larmond, 1977) within $3 \mathrm{~d}$ after pasteurisation by 41 panellists using the triangle test (Roessler et al., 1978), a sensory evaluation procedure that will indicate if detectable differences exist between samples. Two identical samples and one odd sample comprised each set of samples tasted by panellists. Panellists were asked to select the odd sample from each set, determine the degree of difference between duplicate samples, and indicate any possible off-flavours in the milk samples.

\section{Statistical analysis}

Data concerning milk chemical composition and immune responses were analysed with the Statistical Analysis System package (SAS, 1999). All data were analysed with analyses of variance for repeated measures with dietary treatment as non-repeated factor and time and time $\mathrm{x}$ treatment as repeated factors.

Data gathered from the triangle difference test were compiled and computed to determine statistical significance based on the number of correct responses ( $\chi^{2}$ one sample test), where the expected frequency of the odd sample was $33.3 \%$.

\section{Results and discussion}

Keyhole limpet haemocyanin antibody production and in vivo cellmediated immunity dietary supplementation did not affect antibody response against KLH. These results are in agreement with those previously reported in lactating cows (Lessard et al., 2003, 2004), in dogs (Wander et al., 1997), rats (Fritsche et al., 1992) and laying hens (Sijben et al., 2002), indicating that n-3 PUFA have no effect on antibody response.

However, in the present study a significant $(\mathrm{P}<0.05)$ interaction time $x$ group was found for humoral immune response (Figure 1); both supplemented groups showed evidence of increased antibody response 4, 5, 6, 7 and 8 weeks after antigen administration (secondary response), whereas no differences were observed at 1,2 and 3 weeks (primary response). Analogously, Ballou and Depeters (2008) found no significant effect of supplementing milk replacer with omega 3 fatty acids from fish oil, on primary humoral response of Jersey calves, whereas a quadratic effect of dietary treatment was evident on the secondary humoral response.

Cellular immune response to a percutaneous injection of PHA (Figure 2) was significantly affected by group $(\mathrm{P}<0.05)$. In particular, supplemented groups showed higher cellular response in both skin tests compared to control animals. The change in skin thickness after an intradermal injection of PHA-P is the result of a complex series of events such as mitogen-receptor and lymphocyte-macrophage interactions, the release of chemical mediators, changes in vascularity, and cellular proliferation (Lochmiller et al., 1993). Dietary fatty acids can influence immunity through the production of cytokines and molecules involved in the regulation of immune responses. In particular, omega3 polyunsaturated FA are important immunomodulators of immune reactions (Calder et al., 2002). Although, the effects of n-3 PUFAs are influenced by the level of vitamin $\mathrm{E}$ present in the diet, suggesting that the balance between the n-3 PUFAs and vitamin E will be important in

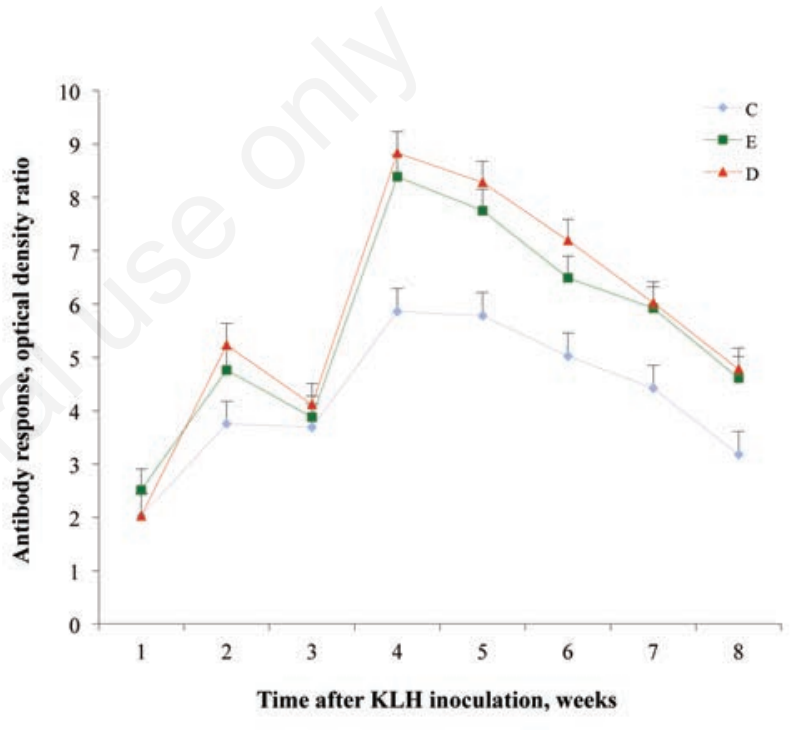

Figure 1. Antibody response against keyhole limpet haemocyanin (KLH) in dairy cows supplemented with docosahexaenoic acid (DHA) (group D), with DHA + vitamin E (group E) and receiving no supplementation (group C). Cows were injected with KLH at the end of the supplementation period and 2 weeks later. Antibody against KLH was measured by ELISA and quantified based on optical density measurement.

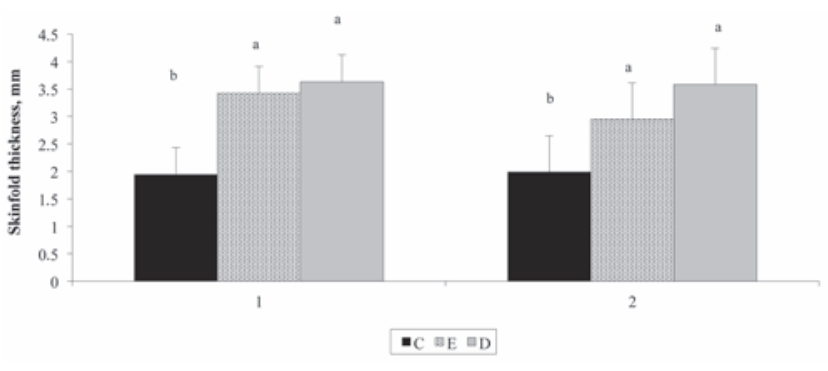

Figure 2. Reaction of dairy cattle supplemented with docosahexaenoic acid (DHA) (group D), with DHA + vitamin E (group E) and receiving no supplementation (group C) to two skin tests. Phytohaemaglutinin was intradermally injected at the end of the supplementation period and 8 weeks later and skinfold thickness measured as $24 \mathrm{~h}$ thickness - pre-injection thickness. 
determining the overall functional outcome (Calder, 1998), we found no significant additional effects of vitamin $\mathrm{E}$ on cattle cellular immune response. Natural antioxidants, such as vitamin E, are very important in protecting animal's tissues from oxidative destruction. This protective benefit may result in an improved immune response (Nockels, 1996) as dietary PUFA and vitamin E may interact and protect PUFA from in vivo oxidation. However, Sijben et al. (2002) found this interaction of minor importance as compared to the separate effects of PUFA.

\section{Milk production and fatty acid composition}

Dietary treatment did not show any significant effect on daily milk yield, protein, fat and lactose content (Table 3). This result is in agreement with Stamey et al. (2012) who found no detrimental influence on milk yield or milk fat yield in Holstein cows receiving rumen protected algal biomass or rumen protected algal oil. In the present study the form of algae supplementation was protected similarly to that used by Stamey et al. (2012). Similarly, Moate et al. (2013), offering different amounts of algal meal to lactating cows, found no alterations on milk yield although milk fat yield decreased with the addition of DHA. On the contrary, other authors (Franklin et al., 1999; Boeckaert et al., 2008; Hostens et al., 2011), supplementing cows with unprotected marine algae observed a reduction in dry matter intake (DMI) and milk yield. In general, a large amounts of fat in the diet of ruminants, and particularly high level of PUFA in unprotected form, is not recommended, as it has a negative effect on the activity of the rumen microflora, with changes in the pattern of rumen biohydrogenation that leads to accumulation of trans FA in the rumen, and inhibition of milk fat synthesis in the mammary gland (Bauman and Griinari, 2003). In the present study, the slight effect of fat supplementation on milk yield may be attributed also to the stage of lactation; cows in mid lactation are in a positive energy balance, and likely will not benefit from the extra dietary energy, provided that they are producing milk to their genetic potential.

Marine algae supplementation did not markedly affect milk fatty acid profile (Table 4). These results are in contrast with other authors (Franklin et al., 1999; Vahamani et al., 2013) who found a significant change in milk fatty acid composition from cows fed marine algae, with increased total UFA and decreased SFA levels.

Transfer efficiency of FA to the mammary gland decreases with increased DMI, probably indicating partition of nutrients toward adipose tissue as the animal reaches positive energy balance (Grummer, 1991). The extent to which the supplementation of fat higher in PUFA altered the FA composition of milk depends on a number of factors including the degree of ruminal biohydrogenation, the composition of the non-lipid components of the diet, the desaturase activity in the intestine and mammary gland, the influence of the lipid source on microbial FA synthesis and de novo synthesis of FA in the mammary gland (Kennelly, 1996).

In the present study, DHA percentage significantly increased in D and $\mathrm{E}$ treatments compared with the control group $(0.11 \pm 0.02 \%$ and $0.13 \pm 0.02 \%$ vs $0.07 \pm 0.02 \%$, respectively; $\mathrm{P}<0.05$ ). The little increase observed may be probably due to the transfer efficiency of DHA from the diet to the milk. In fact, with the exception of Kitessa et al. (2004) who reported a DHA transfer of $18 \%$ with rumen protected tuna oil, Franklin et al. (1999) reported DHA transfer efficiencies of $8 \%$ and $16 \%$ with unprotected and protected algal supplements, respectively; Boeckaert et al. (2008) found transfer efficiencies of 5.9 and $3.1 \%$ in early and late lactation, respectively, while Stamey et al. (2012) observed a transfer efficiency of $2 \%$. Lower transfer efficiency may be due to biohydrogenation in the rumen and to the length of the supplementation. According to Franklin et al. (1999), probably rumen micro organisms need some time to adjust to the presence of supplementation, thus milk DHA response to dietary marine algae decreases. In addition, the transfer efficiency of UFA from diet to milk can be due to the stage of lactation as Kennelly (1996) reported different effects of feeding whole canola seeds on fatty acid composition of milk as function of calving distance. In the present study, the low DHA increase obtained in milk by algae supplementation may be due to the later stage of lactation of the cows used in the experiment (Stamey et al., 2012). As previously found in cows supplemented with marine algae (Stamey et al., 2012; Vahamani et al., 2013), the concentration of trans18:1 was significantly greater in supplemented groups $(2.51 \pm 0.02 \%$ and $2.83 \pm 0.02 \%$ vs $2.12 \pm 0.02 \%$, for D, E and C groups respectively;

Table 3. Yield and chemical composition (means $\pm S E$ ) of milk from control animals (group C) and from animals supplemented with docosahexaenoic acid (DHA) (group D) or DHA + vitamin E (group E).

\begin{tabular}{lcccc} 
& C & D & E & P \\
Milk yield, kg & $13.2 \pm 2.24$ & $15.1 \pm 2.07$ & $14.9 \pm 2.03$ & ns \\
Fat, \% & $2.34 \pm 0.23$ & $3.61 \pm 0.21$ & $3.54 \pm 0.21$ & ns \\
\hline Proteins, \% & $3.39 \pm 0.09$ & $3.39 \pm 0.08$ & $3.58 \pm 0.08$ & ns \\
Lactose, \% & $4.91 \pm 0.09$ & $4.92 \pm 0.08$ & $4.87 \pm 0.08$ & ns \\
\hline
\end{tabular}

ns, not significant.

Table 4. Fatty acid composition (means \pm SE) of milk from control animals (group C) and from animals supplemented with docosahexaenoic acid (DHA) (group D) or DHA + vitamin E (group E).

\begin{tabular}{|c|c|c|c|c|}
\hline & C & D & E & P \\
\hline C14:0 & $9.69 \pm 0.35$ & $9.57 \pm 0.33$ & $9.43 \pm 0.33$ & ns \\
\hline C16:0 & $31.97 \pm 0.73$ & $32.46 \pm 0.67$ & $32.06 \pm 0.67$ & ns \\
\hline C18:0 & $8.93 \pm 0.35$ & $8.80 \pm 0.33$ & $8.93 \pm 0.33$ & ns \\
\hline Cl8:1 $1 \omega 9$ & $22.18 \pm 0.99$ & $22.29 \pm 0.92$ & $22.28 \pm 0.91$ & ns \\
\hline $\mathrm{C} 18: 2 \omega 6$ & $2.33 \pm 0.12$ & $2.15 \pm 0.11$ & $2.21 \pm 0.11$ & ns \\
\hline $\mathrm{C} 18: 3 \omega 3$ & $0.56 \pm 0.06$ & $0.58 \pm 0.05$ & $0.63 \pm 0.05$ & ns \\
\hline Saturated, \% & $67.69 \pm 1.42$ & $67.10 \pm 1.32$ & $66.08 \pm 1.32$ & ns \\
\hline Monounsaturated, \% & $27.90 \pm 1.26$ & $28.42 \pm 1.16$ & $29.13 \pm 1.16$ & ns \\
\hline Polyunsaturated, \% & $3.60 \pm 0.02$ & $4.49 \pm 0.02$ & $4.79 \pm 0.02$ & ns \\
\hline Trans, $\%$ & $2.88 \pm 0.03$ & $3.33 \pm 0.02$ & $3.72 \pm 0.02$ & ns \\
\hline$\sum \mathrm{n}-3, \%$ & $0.93 \pm 0.08$ & $1.02 \pm 0.08$ & $1.02 \pm 0.08$ & ns \\
\hline$\sum \mathrm{n}-6, \%$ & $3.07 \pm 0.01$ & $2.84 \pm 0.01$ & $3.04 \pm 0.01$ & ns \\
\hline$\sum n-6 / \Sigma n-3$ & $3.60 \pm 0.03$ & $2.83 \pm 0.03$ & $3.02 \pm 0.03$ & ns \\
\hline
\end{tabular}

Table 5. Degree of discrimination between milk from control animals (group C) and from animals supplemented with docosahexaenoic acid (DHA) (group D) or DHA + vitamin E (group E).

\begin{tabular}{lcccc} 
& $\begin{array}{c}\text { Total } \\
\text { responses } \\
\text { (n) }\end{array}$ & $\begin{array}{c}\text { Correct } \\
\text { responses } \\
(\mathrm{n})\end{array}$ & $\begin{array}{c}\text { Correct } \\
\text { responses }\end{array}$ & P \\
\hline C vs D & 41 & 29 & 71 & $* * *$ \\
E vs C & 41 & 25 & 61 & $* * *$ \\
\hline E vs D & 41 & 15 & 36 & ns \\
\hline
\end{tabular}

*** $\mathrm{P}<0.001$. ns, not significant. 
$\mathrm{P}<0.05)$. Although algal DHA was rumen-protected, the increase in trans-C18:1 percentage in milk FA observed in milk from E and D groups suggests that supplementation can inhibit the last step of ruminal hydrogenation from trans-C18:1 to C18:0. According to AbuGhazaleh and Jenkins (2004), DHA is a stronger inhibitor of ruminal biohydrogenation, resulting in the accumulation of ruminal biohydrogenation intermediates, such as trans 18:1 isomers in the rumen whereas Klein and Jenkins (2011) stated that DHA modifies biohydrogenation of other long-chain PUFA in the rumen (e.g. linoleic and linoleic acids).

\section{Sensory evaluation}

Although Kitessa et al. (2004) reported that triangle panel test did not differentiate the $\mathrm{n}-3$ fatty acid enriched milk (by tuna oil diet supplementation) from the control milk sample, in the present study panellists detected significant differences $(\mathrm{P}<0.001)$ between $\mathrm{C} v s \mathrm{D}$ and $\mathrm{E}$ milk samples (Table 5). Similar results were obtained by Franklin et al. (1999). Stegeman et al. (1992) reported that milk from cows receiving supplemental oilseeds was equal or superior in quality to control milk as judged by sensory evaluation. On the contrary, other authors (Nelson and Martini, 2009) fed cows with fish oil (protected or unprotected) and observed that milk was more prone to oxidation, thus affecting sensory properties. In fact, oxidation of PUFAs produces a complex mixture of volatile secondary oxidation products, some of them producing off-flavours (Let et al., 2005).

No effect of vitamin E on milk sensory properties was observed as samples gathered from groups D and E were not discriminated.

\section{Conclusions}

The supplementation of diets with marine algae in a late stage of lactation increased cattle immune-responsiveness but did not markedly affect milk traits and fatty acid profile. Nevertheless, a significant increase in percentage of DHA and a marked modification of sensory properties were observed in the milk of treated groups. Thus, although provided in a late stage of lactation, a n-3 fatty acid enriched diet favourably changed milk fatty acid profile, from a nutritional point of view, and promoted animal healthiness by enhancing cellular and humoral immune response.

\section{References}

AbuGhazaleh AA, Jenkins TC, 2004. Short communication: docosahexaenoic acid promotes vaccenic acid accumulation in mixed ruminal cultures when incubated with linoleic acid. J. Dairy Sci. 87:1047-50.

Arab-Tehrany E, Jacquot M, Gaiani C, Imran M, Desobry S, Linder M, 2012. Beneficial effects and oxidative stability of omega-3 longchain polyunsaturated fatty acids. Trends Food Sci. Tech. 25:24-33.

Barclay W, Abril R, Abril P, Weaver C, Ashford A, 1998. Production of docoshexaenoic acid from microalgae and its benefits for use in animal feeds. In: A.P. Simopoulos (ed.), The return of 3 fatty acids into the food supply. I. Land-based animal food products and their health effects. World Review of Nutrition and Diet, Vol. 83. Karger Publ., Basel, Switzerland, pp 61-76.

Ballou MA, DePeters EJ, 2008. Supplementing milk replacer with omega-3 fatty acids from fish oil on immunocompetence and health of Jersey calves. J. Dairy Sci. 91:3488-500.

Bauman DE, Griinari JM, 2003. Nutritional regulation of milk fat syn- thesis. Annu. Rev. Nutr. 23:203-27.

Bligh E, Dyer WJ, 1959. A rapid method of total lipid extraction and purification. Can. J. Biochem. Phys. 37:911-7.

Boeckaert C, Vlaeminck B, Dijkstra J, Issa-Zacharia A, Van Nespen T, Van Straalen W, Fievez V, 2008. Effect of dietary starch or micro algae supplementation on rumen fermentation and milk fatty acid composition of dairy cows. J. Dairy Sci. 91:4714-27.

Calder PC, 1998. Fat chance of immunomodulation. Immunol. Today 192:244-7.

Calder PC, Yaqoob P, Thies F, Wallace FA, Miles EA, 2002. Fatty acids and lymphocyte functions. Br. J. Nutr. 87:S31-48.

Chilliard Y, Ferlay A, Doreau M, 2001. Effect of different types of forages, animal fat or marine oils in cow's diet on milk fat secretion and composition, especially conjugated linoleic acid (CLA) and polyunsaturated fatty acids. Liv. Prod. Sci. 70:31-48.

Collomb M, Sollberger H, Butikofer U, Sieber R, Stoll W, Schaeren W, 2004. Impact of a basal diet of hay and fodder beet supplemented with rapeseed, linseed and sunflower seed on the fatty acid composition of milk fat. Int. Dairy J. 14:549-59.

Fox PF, McSweeney PLH, 1998. Dairy chemistry and biochemistry, 1st ed. Blackie Academic \& Professional, London, UK.

Franklin ST, Martin KR, Baer RJ, Schingoethe DJ, Hippen AR, 1999. Dietary marine algae (Schizochytrium sp.) increases concentrations of conjugated linoleic, docosahexenaenoic and transvaccenic acids in milk of dairy cows. J. Nutr. 129:2048-52.

Fritsche KL, Cassity NA, Huang SC, 1992. Dietary (n-3) fatty acid and vitamin $\mathrm{E}$ interactions in rats: effects on vitamin $\mathrm{E}$ status, immune cell prostaglandin E production and primary antibody response. J. Nutr. 122:1009-18.

Granelli K, Barrefors P, Bjoerck L, Appelqvist LA, 1998. Further studies on lipid composition of bovine milk in relation to spontaneous oxidised flavour. J. Sci. Food Agr. 77:161-71.

Grummer RR, 1991. Effect of feed on the composition of milk fat. J. Dairy Sci. 74:3244-57.

Hostens M, Fievez V, Vlaeminck B, Buyse J, Leroy J, Piepers S, De Vliegher S, Opsomer G, 2011. The effect of marine algae in the ration of high-yielding dairy cows during transition on metabolic parameters in serum and follicular fluid around parturition. J. Dairy Sci. 94:4603-15.

Huth PJ, DiRienzo DB, Miller GD, 2006. Major scientific advances with dairy foods in nutrition and health. J. Dairy Sci. 89:1207-21.

Huth PJ, Park KM, 2012. Influence of dairy product and milk fat consumption on cardiovascular disease risk: a review of the evidence. Adv. Nutr. 3:266-85.

Jenkins TC, McGuire MA, 2006. Major advances in nutrition: impact on milk composition. J. Dairy Sci. 89:1302-10.

Kennelly JJ, 1996. The fatty acid composition of milk fat as influenced by feeding oilseeds. Anim. Feed Sci. Tech. 60:137-52.

Kitessa SM, Gulati SK, Simos GC, Ashes JR, Scott TW, Fleck E, Wynn PC, 2004. Supplementation of grazing dairy cows with rumen-protected tuna oil enriches milk fat with n-3 fatty acid without affecting milk production or sensory characteristics. Br. J. Nutr. 91:271-7.

Klein CM, Jenkins TC, 2011. Docosahexaenoic acid elevates trans-18:1 isomers but is not directly converted into trans-18:1 isomers in ruminal batch cultures. J. Dairy Sci. 94:4676-83.

Larmond E, 1977. Laboratory methods for sensory evaluation of food. Agric. Can. Publ. No. 1637. Canada Dept. Agric., Ottawa, ON, Canada.

Lessard M, Gagnon N, Godson DL, Petit HV, 2004. Influence of parturition and diets enriched in n-3 or n- 6 polyunaturated fatty acids on immune response of dairy cows during the transition period. J. Dairy Sci. 87:2197-10.

Lessard M, Gagnon N, Petit HV, 2003. Immune response of postpartum 
dairy cows fed flaxseed. J. Dairy Sci. 86:2647-57.

Let MB, Jacobsen C, Meyer AS, 2005. Sensory stability and oxidation of fish oil enriched milk is affected by milk storage temperature and oil quality. Int. Dairy J. 15:173-82.

Lochmiller RL, Vestey MR, McMurry ST, 1993. Selected immune responses of adult cotton rats (Sigmodon hispidus) to dietary restriction. Comp. Biochem. Physiol. 104:593-9.

Mansbridge RJ, Blake JS, 1997. Nutritional factors affecting the fatty acid composition of bovine milk. Br. J. Nutr. 78:S37-47.

Moate PJ, Williams SRO, Hannah MC, Eckard RJ, Auldist MJ, Ribaux $\mathrm{BE}$, Jacobs JL, Wales WJ, 2013. Effects of feeding algal meal high in docosahexaenoic acid on feed intake, milk production, and methane emissions in dairy cows. J. Dairy Sci. 96:3177-88.

Nelson KAS, Martini S, 2009. Increasing omega fatty acid content in cow's milk through diet manipulation: effect on milk flavor. J. Dairy Sci. 92:1378-86.

Nockels CF, 1996. Antioxidants improve cattle immunity following stress. Anim. Feed Sci. Tech. 62:59-68.

Pomposelli JJ, Mascioli EA, Bistrian BR, Lopezand SM, Blackburn GL, 1989. Attenuation of the febrile response in guinea pigs by fish oil enriched diets. J. Parenteral Enteral Nutr. 13:136-40.

Riediger ND Msc, Othman RA Msc, Suh M, Moghadasian MH, 2009. A systemic review of the roles of n-3 fatty acids in health and disease. J. Am. Diet. Assoc. 109:668-79.

Roessler EB, Pangborn RM, Sidel JL, Stone H, 1978. Expanded statistical tables for estimating significance in paired-preference, paired- difference, duo-trio and triangle tests. J. Food Sci. 43: 940-947.

Sijben JW, Schrama JW, Nieuwland MG, Hovenier R, Beynen AC, Verstegen MW, Parmentier HK, 2002. Interactions of dietary polyunsaturated fatty acids and vitamin $\mathrm{E}$ with regard to vitamin $\mathrm{E}$ status, fat composition and antibody responsiveness in layer hens. Br. Poult. Sci. 43:297-305.

Shingfield KJ, Chilliard Y, Toivonen V, Kairenius P, Givens DI, 2008. Bioactive components of milk. Vol. 606. Springer-Verlag, Berlin, Germany, pp 3-65.

Stamey JA, Shepherd DM, de Veth MJ, Corl BA, 2012. Use of algae or algal oil rich in n-3 fatty acids as a feed supplement for dairy cattle. J. Dairy Sci. 95:5269-75.

Stegeman GA, Baer RJ, Scingoethe DJ, Casper D, 1992. Composition and flavour of milk and butter from cows fed unsaturated dietary fat and receiving bovine somatotropin. J. Dairy Sci. 75:962-70.

Stenson WF, Cort D, Rodgers J, Burakoff R, De Schryver-Kecskemeti K, Gramlich TL, Beeken W, 1992. Dietary supplementation with fish oil in ulcerative colitis. Ann. Intern. Med. 116:609-14.

Vahmani P, Fredeen AH, Giover KE, 2013. Effect of supplementation with fish oil or microalgae on fatty acid composition of milk from cows managed in confinement or pasture systems. J. Dairy Sci. 96: 6660-70.

Wander RC, Hall JA, Gradin JL, Du SH, Jewell DE, 1997. The ratio of dietary (n-6) to (n-3) fatty acids influences immune system function, eicosanoid metabolism, lipid peroxidation and vitamin E status in aged dogs. J. Nutr. 127:1198-205. 